\title{
OTWARTE INNOWACJE W INICJATYWACH KLASTROWYCH
}

https://doi.org/10.33141/po.2019.04.03

\section{Anna Maria Lis, Adrian Lis}

Przegląd Organizacji, Nr 4 (951), 2019, ss. 18-26

www.przegladorganizacji.pl OTowarzystwo Naukowe Organizacji i Kierownictwa (TNOiK)

\section{Wprowadzenie}

$J$ edną z dróg, jakie może wybrać przedsiębiorstwo planujące zwiększenie swojej konkurencyjności na rynku, jest zaangażowanie się $\mathrm{w}$ relacje współpracy $\mathrm{z}$ innymi podmiotami gospodarczymi lub organizacjami o komplementarnym charakterze (np. instytucjami otoczenia biznesu, jednostkami naukowo-badawczymi). Kooperacja taka wymuszona jest przez niemożliwość osiągnięcia stanu samowystarczalności przez jakiekolwiek przedsiębiorstwo - niezależnie od tego, czy stan ten miałby dotyczyć jego zasobów materialnych czy niematerialnych. Zwrócili na to uwagę np. autorzy teorii zależności od zasobów (resource dependence theory) - J. Pfeffer i G. Salancik (2003) - wskazując, że uzależnienie organizacji od zasobów znajdujących się w ich otoczeniu jest czynnikiem nakłaniajacym te podmioty do wchodzenia w mniej lub bardziej trwałe relacje wymiany $\mathrm{z}$ innymi organizacjami.

Organizacje - a więc i przedsiębiorstwa - różnią się między sobą nie tylko stanem zasobów pozostających do ich dyspozycji, ale także i planowaną (lub nieplanowaną) efektywnością ich wykorzystania. Obok przedsiębiorstw, w których ambicje i strategia działania dopasowane są optymalnie do posiadanych zasobów, funkcjonują także i przedsiębiorstwa o dużym potencjale zasobowym, ale o niewielkich ambicjach lub strategii niewymuszającej zaangażowania całości zasobów (podmioty Alpha) oraz przedsiębiorstwa stawiające sobie odważne cele i dążące do ich realizacji pomimo względnie mniejszych możliwości (podmioty Beta) (Hamel, Prahalad, 1993). Podmiotami Alpha często zostają liderzy rynku uspokojeni swoją dominującą pozycją, zaś podmioty Beta to ich głodni sukcesu konkurenci, starający się wykorzystać każdą szansę na poprawienie swojej pozycji konkurencyjnej. Głównym środkiem służącym przemianie podmiotów Beta w podmioty Alpha jest tzw. „rozciągnięcie” (stretch) zasobów, czyli takie zagospodarowanie aktualnego stanu posiadania, które zmaksymalizuje efektywność wykorzystania tych zasobów i umożliwi osiągnięcie efektów przekraczających przeciętny poziom przewidywany dla podmiotów o zbliżonym potencjale.

Wspomniane „rozciągnięcie” zasobów jest możliwe do przeprowadzenia na dwa sposoby: poprzez zmniejszenie zapotrzebowania na nie, a więc pewną redukcję potencjału (np. zwolnienia pracowników, zmniejszenie inwestycji) lub zastosowanie tzw. „dźwigni zasobów” (resource leverage). O ile jednak strategia zmniejszania potencjału często działa demoralizująco na całą organizację, o tyle „dźwignia zasobów” ma pozytywny wpływ na produktywność danego podmiotu (Hamel, Prahalad, 1993). Jak wskazują G. Hamel i C.K. Prahalad (1993), wspomnianą „dźwignię zasobów” można zastosować na pięć różnych sposobów: poprzez koncentrację, akumulowanie, dopasowywanie, ochronę oraz odzyskiwanie zasobów. A ponieważ - zgodnie z zasobową teorią przedsiębiorstwa - zasoby kluczowe dla organizacji powinny być wartościowe, rzadkie, nieimitowalne i niezastępowalne (Lockett i in., 2009), istotną rolę $\mathrm{w}$ ich tworzeniu, pomnażaniu i konwersji odgrywać musi innowacyjność.

Jako że to właśnie wspomniane na początku relacje współpracy nawiązywanej przez przedsiębiorstwo $\mathrm{z}$ innymi podmiotami są uznane za oddziałujące pozytywnie na innowacyjność podmiotów gospodarczych (Balconi i in., $2004)^{1}$, warto zwrócić baczniejszą uwagę na sformalizowane struktury wyższego rzędu łączące przedsiębiorstwa funkcjonujące $\mathrm{w}$ różnych sektorach gospodarki (oraz organizacje o innym charakterze niż gospodarczy), tworzące naturalnie sprzyjające warunki do współpracy, a więc i wzrostu innowacyjności ich uczestników - inicjatywy klastrowe. Należy bowiem podkreślić, iż o innowacyjności przedsiębiorstwa nie decydują tylko czynniki wewnętrzne; wpływa na to również system wparcia innowacji, jeden z elementów „triady innowacji” (Romanowska, 2015). To właśnie w tej kategorii umieścić należy inicjatywy klastrowe, stanowiące przykład narzędzi polityki innowacyjnej. Otwartość inicjatyw klastrowych i pełnienie przez nie roli platformy wspólnej działalności składających się na nią podmiotów (w tym przedsiębiorstw) jest czynnikiem predysponującym inicjatywy klastrowe do rozwoju innowacji otwartych (open innovation).

Celem niniejszego artykułu jest przedstawienie powiązań poziomów współpracy klastrowej, wyróżnionych w autorskiej koncepcji trajektorii rozwoju powiązań kooperacyjnych $\mathrm{w}$ inicjatywach klastrowych $\mathrm{z}$ elementami konstytuującymi innowacje otwarte. Artykuł składa się z pięciu części: na początku omówiono specyfikę innowacji otwartych oraz inicjatyw klastrowych, zaprezentowano metodykę badawczą, następnie przedstawiono koncepcję teoretyczną wiążącą ze sobą oba omawiane terminy i przeprowadzono dyskusję, na koniec zaś zawarte zostały główne wnioski i zalecenia dla przyszłych badań w analizowanym obszarze. 


\section{Przegląd literatury}

$\mathbf{S}$ chumpeterowska wizja gospodarki - systemu wewnątrzsterownego dążącego do zachowania swojej równowagi poprzez odtwarzanie się - nie uzyskałaby zapewne swojej wielkiej popularności w nauce, gdyby austriacki ekonomista nie uwzględnił w niej czynników wyrywających ów system $\mathrm{z}$ utartych ścieżek cykliczności: przedsiębiorcy, innowacji i kredytu (Schumpeter, 1911; 1939; 1942). Rolą przedsiębiorcy miało być wykorzystanie środków produkcji w nowy sposób (zastosowanie ich nowej kombinacji), co w rezultacie oznaczało wprowadzenie innowacji do praktyki gospodarczej. Za innowację J.A. Schumpeter uważał natomiast: wprowadzenie na rynek nowego lub istotnie unowocześnionego produktu, zastosowanie nowego sposobu produkcji (lub sprzedaży), wejście na nowy rynek, pozyskanie nowych źródeł surowców bądź półproduktów oraz branżową restrukturyzację (przede wszystkim w formie stworzenia nowego $\mathrm{i} / \mathrm{lub}$ zniszczenia istniejącego monopolu) (Schumpeter, 1934). Ponieważ wysiłek taki często nie mógł być podjęty na bazie aktualnie posiadanych przez przedsiębiorcę środków finansowych, istotnym elementem działań innowacyjnych stał się kredyt bankowy.

Mijające lata i zmieniające się warunki prowadzenia działalności gospodarczej oraz powstawanie wciąż nowych ujęć „innowacji” w nauce doprowadziły do sytuacji, w której pojęcie to uzyskało cały szereg nowych znaczeń i stało się podstawą wielu różnych, często bardzo rozbudowanych klasyfikacji (Cumming, 1998). Jednocześnie jednak spora część z tych teoretycznych propozycji odeszła dość daleko od pierwotnej idei innowacji schumpeterowskiej, zawężając jej specyfikę do bycia nowością przede wszystkim w aspekcie technologii (Marques, 2014). Swoistym wyłamaniem się z tego trendu i - jednocześnie - kontynuacją dość szerokiego myślenia o innowacjach jest definicja B. Lundvalla (1992), zgodnie z którą innowacja to „ciągłe procesy uczenia się, wyszukiwania i odkrywania, które skutkują nowymi produktami, nowymi technikami, nowymi formami organizacji i nowymi rynkami”. Odejście od takiego klasycznego ujęcia innowacji widoczne jest jednak również w nadużywaniu terminów, takich jak ,innowacyjna gospodarka” czy ,innowacyjne rozwiązania" (szczególnie w nomenklaturze administracji unijnej i państwowej), które - jak celnie zauważa U. Zagóra-Jonszta (2015) - są bardzo często wykorzystywane na oznaczenie ostatniego z elementów schumpeterowskiej „triady”, czyli działań imitacyjnych.

Ewolucja pojęcia „innowacji” doprowadziła naukowców i praktyków do punktu, w którym pod dyskusję poddawane jest nie tyle samo rozumienie „innowacji”, co sposób prowadzenia działań zorientowanych na wytworzenie nowej jakości. Modna obecnie ${ }^{2}$ koncepcja innowacji otwartych (Kozarkiewicz, 2010) - interesująca z punktu widzenia możliwości jej naturalnej aplikacji do struktur klastrowych - nie jest w rzeczywistości koncepcją innowacji, ale pewnej idei dochodzenia do rozwiązań o charakterze innowacyjnym. Wprowadzający pojęcie „innowacji otwartych” do literatury przed- miotu H.W. Chesbrough rozumiał je jako: „wykorzystanie celowych przypływów i wypływów wiedzy w celu przyspieszenia wewnętrznych innowacji i rozszerzenia rynków dla zewnętrznego wykorzystania innowacji. [Ten paradygmat] zakłada, że przedsiębiorstwa mogą i powinny wykorzystywać zarówno zewnętrzne, jak i wewnętrzne pomysły (...), gdy szukają możliwości rozwoju swojej technologii" (Chesbrough, 2006). Także i w późniejszej definicji H.W. Chesbrough wyraźnie odnosił się do procesu kreowania innowacji, a nie innowacji jako takich, pisząc: „dalej wyjaśniamy i rozwijamy koncepcję otwartej innowacji, którą definiujemy jako rozproszony proces innowacji oparty na celowo zarządzanym przepływie wiedzy ponad granicami organizacyjnymi, wykorzystujący mechanizmy pieniężne i niepieniężne zgodnie $\mathrm{z}$ modelem biznesowym organizacji” (Chesbrough, Bogers, 2014).

H.W. Chesbrough wyróżnił poza tym trzy zasadnicze kierunki innowacji otwartych, jakie może obrać dany podmiot zorientowany na innowacyjność: dośrodkowy („Outside-In” lub Inbound), odśrodkowy („Inside-Out” lub Outbound) i sprzężony („Coupled”). Kierunek „Outside-In" to otwartość na idee i rozwiązania pochodzące spoza podmiotu, ale przez ten podmiot pozyskiwane, internalizowane i aplikowane (a często i dalej przez ten podmiot rozwijane). Jak jednocześnie wskazują J. West i M. Bogers - podejście „Outside-In” było przedmiotem większej liczby analiz naukowych niż dwa pozostałe wymienione (West, Bogers, 2014) ${ }^{3}$. W wariancie „Inside-Out" organizacje kreujące rozwiązania innowacyjne dysponują mechanizmami dystrybuowania swoich wytworów na zewnątrz - poza tę organizację. Natomiast ostatni z wyróżnionych typów innowacji otwartych -„Coupled”- stanowi połączenie tendencji dośrodkowych i odśrodkowych: organizacje działające w ramach modelu sprzężonego łączą umiejętności pozyskiwania określonych rozwiązań $\mathrm{z}$ otoczenia ze zdolnością do transferowania własnych wytworów na zewnątrz (Chesbrough, Bogers, 2014). Trzeba jednakże podkreślić - ze względu na specyfikę struktur klastrowych stanowiących przedmiot rozważań $\mathrm{w}$ niniejszym artykule - silne powiązanie każdego z wyżej omówionych typów innowacji otwartych z problematyką kooperacji (każdy typ innowacji otwartych zakłada współpracę z innymi podmiota$\mathrm{mi})$. Kooperacja odgrywa szczególnie istotną rolę w wariancie "Coupled”: „Sprzężony typ otwartej innowacji obejmuje połączenie celowych przypływów i wypływów wiedzy w celu wspólnego opracowania i/lub komercjalizacji innowacji. W sprzężonej otwartej innowacji występuje dwóch (lub więcej) partnerów, którzy celowo zarządzają dwukierunkowym przepływem wiedzy w obrębie swoich granic organizacyjnych w oparciu o wspólne działania związane z wynalazkami i ich komercjalizacją" (Chesbrough, Bogers, 2014; Bogers, 2011). W każdym $\mathrm{z}$ wariantów podstawowym dobrem podlegającym wytworzeniu, absorpcji i transferowi między organizacjami jest wiedza. W tabeli 1 zawarto najważniejsze ustalenia dotyczące specyfiki innowacji otwartych dokonane na podstawie przeglądu literatury. 
Tabela 1. Specyfika innowacji otwartych

\begin{tabular}{|c|c|}
\hline $\begin{array}{c}\text { Cecha } \\
\text { charakterystyczna }\end{array}$ & Opis \\
\hline $\begin{array}{l}\text { Szerokie podejście } \\
\text { w definiowaniu innowacji }\end{array}$ & $\begin{array}{l}\text { Odejście od postrzegania innowacji } \\
\text { przez pryzmat rozwoju technologii. }\end{array}$ \\
\hline $\begin{array}{l}\text { Wiedza - podstawowy } \\
\text { zasób organizacji }\end{array}$ & $\begin{array}{l}\text { Utożsamianie innowacji otwartych } \\
\text { z procesami kolektywnego kreowania, } \\
\text { współdzielenia i dystrybucji nowej } \\
\text { wiedzy. }\end{array}$ \\
\hline $\begin{array}{l}\text { Siła relacji } \\
\text { międzyorganizacyjnych } \\
\text { w pozyskiwaniu wiedzy }\end{array}$ & $\begin{array}{l}\text { Coraz większe docenienie siły } \\
\text { powiązań w procesie innowacyjnym, } \\
\text { wspierających transfer wiedzy cichej } \\
\text { i uczenie się. }\end{array}$ \\
\hline $\begin{array}{l}\text { Otwartość na idee } \\
\text { pochodzące spoza } \\
\text { organizacji }\end{array}$ & $\begin{array}{l}\text { Pozyskiwanie wiedzy zarówno } \\
\text { ze źródeł wewnętrznych, jak } \\
\text { i zewnętrznych. }\end{array}$ \\
\hline Przepływy wiedzy & $\begin{array}{l}\text { Zwrócenie uwagi na } \\
\text { wielokierunkowość innowacji } \\
\text { otwartych (dośrodkowy, odśrodkowy } \\
\text { i sprzężony model otwartej innowacji). }\end{array}$ \\
\hline
\end{tabular}

Źródło: opracowanie własne

Zważywszy na to, że innowacje otwarte to tak naprawdę procesy kolektywnego kreowania, współdzielenia i dystrybucji nowych rozwiązań (nowej wiedzy), nieprzypadkowy był wybór typu organizacji, na przykładzie której autorzy przeprowadzili badania i rozważania teoretyczne. Inicjatywy klastrowe bowiem, ze względu na swoją specyfikę, idealnie nadają się do obserwacji rzeczywistego funkcjonowania mechanizmów innowacji otwartych. Koncepcja klastrów M.E. Portera $(1998 ; 2000)$ - chronologicznie poprzedzająca koncepcję inicjatyw klastrowych i będąca zarazem dla niej podstawą - była kolejnym $z$ etapów naukowej refleksji podejmowanej przez kolejne pokolenia badaczy zainteresowanych współpracą podmiotów gospodarczych pozostających w geograficznej bliskości. Zgodnie $\mathrm{z}$ jedną ze sformułowanych przez M.E. Portera definicji, klaster to "geograficzne skupiska wzajemnie powiązanych firm, wyspecjalizowanych dostawców, jednostek świadczących usługi, firm działających w pokrewnych sektorach i związanych z nimi instytucji (na przykład uniwersytetów, jednostek normalizacyjnych i stowarzyszeń branżowych) w poszczególnych dziedzinach, konkurujących między sobą, ale także współpracujących" (Porter, 2001, s. 246). Koncepcja M.E. Portera znalazła wielu naśladowców, ale także i przeciwników (Lis, Lis, 2014). Analiza kluczowych, obecnych w literaturze przedmiotu ujęć pojęcia „klaster” umożliwiła autorom sformułowanie takiego rozumienia tego pojęcia, które uwzględnia - w ich mniemaniu - wszystkie najważniejsze cechy dystynktywne tego konstruktu teoretycznego. Zgodnie z ową definicją, klaster to „sektorowa i geograficzna koncentracja przedsiębiorstw powiązanych zależnościami handlowymi i niehandlowymi w ramach łączącej je (w pewnym stopniu) wspólnoty wartości i celów, jednocześnie współdziałających i konkurujących z wykorzystaniem efektu synergii” (Lis, Lis, 2014).
Szczególną odmianą struktury klastrowej jest inicjatywa klastrowa - pojęcie wprowadzone do literatury przez Ö. Sölvella, G. Lindqvista i C. Ketelsana na określenie „zorganizowanych działań mających na celu przyspieszenie rozwoju oraz wzrostu konkurencyjności klastrów $\mathrm{w}$ regionie, obejmujących firmy funkcjonujące w ramach klastra, rząd oraz/lub środowisko badawcze" (Sölvell i in., 2006, s. 9, 17; Sölvell i in., 2003, s. 9, 15). Inicjatywa klastrowa - w odróżnieniu od klastra - posiada atrybuty organizacji. Zgodnie $\mathrm{z}$ definicją A.M. Lis stanowi ona „formalnie powołaną do życia organizację, funkcjonującą na wyższym poziomie zagregowania, złożoną z członków instytucjonalnych (i składających się na nie jednostek), którzy świadomie i dobrowolnie do niej przystąpili, łącząc się ze sobą we współdziałaniu dla osiągnięcia celów zbiorowych (związanych z rozwojem określonego klastra) i/lub celów indywidualnych (związanych $\mathrm{z}$ ich własnym rozwojem)" (Lis, 2018, s, 88). Zarządzanie inicjatywą klastrową polega na koordynacji działań podejmowanych przez członków instytucjonalnych ukierunkowanych na osiągnięcie efektu synergii. Pod tym pojęciem kryje się „zdolność podmiotów będących członkami inicjatywy klastrowej do wytworzenia dodatkowej wartości dzięki pozostawaniu $\mathrm{w}$ relacjach opartych na współdziałaniu z innymi podmiotami, przy czym wartość ta jest wyższa aniżeli suma wartości, która byłaby wytworzona przez każdy z tych podmiotów oddzielnie" (Lis, 2018, s. 88).

\section{Metoda badawcza}

G łówną ideą zawartą w koncepcji innowacji otwartych jest dążenie do rozszerzania posiadanej puli wiedzy przez organizację w oparciu o szeroką współpracę z jej otoczeniem. Istotną rolę $\mathrm{w}$ tym procesie odgrywają zatem relacje współpracy, pozwalające na przepływ wiedzy i informacji pomiędzy podmiotami zaangażowanymi $\mathrm{w}$ rozwój tejże współpracy. Chcąc zidentyfikować elementy innowacji otwartych w inicjatywach klastrowych, wykorzystano do tego koncepcję trajektorii rozwoju powiązań kooperacyjnych $w$ inicjatywach klastrowych, rozwiniętą przez A.M. Lis w badaniach dotyczących współpracy w inicjatywach klastrowych i roli bliskości w rozwoju tejże współpracy (Lis, 2018). Koncepcja trajektorii rozwoju została sformułowana na podstawie wyników badań jakościowych przeprowadzonych przez A.M. Lis w pierwszej połowie 2016 roku w czterech celowo dobranych inicjatywach klastrowych: w dwóch inicjatywach reprezentujących sektor ICT (tj. Mazowiecki Klaster ICT i Interizon Pomorski Klaster ICT) i w dwóch inicjatywach funkcjonujących w branży metalowej (Wschodni Klaster Obróbki Metali i Lubuski Klaster Metalowy) ${ }^{4}$. W ramach badania przeprowadzono pogłębione wywiady bezpośrednie z 34 osobami reprezentującymi koordynatorów oraz wybranych członków badanych inicjatyw klastrowych.

Główną metodą zastosowaną w rozważaniach przeprowadzonych w niniejszym artykule był przegląd literatury przedmiotu dokonany $\mathrm{z}$ wykorzystaniem dostępnych baz danych (m.in. Scopus, Web of Science Core Collection, Google Scholar) oraz aplikacja wspomnianej wyżej autorskiej 
koncepcji trajektorii rozwoju powiązań kooperacyjnych. Istotną pracą, jaką wykonano na tym etapie postępowania badawczego, było zidentyfikowanie głównych cech charakterystycznych innowacji otwartych (na podstawie przeglądu literatury) i podjęcie próby empirycznego zaobserwowania ich występowania w wybranych inicjatywach klastrowych. Autorzy założyli jednak, że w tak zróżnicowanych i często bardzo licznych organizacjach jak inicjatywy klastrowe niemożliwe będzie uzyskanie jednolitego obrazu mechanizmów składających się na innowacje otwarte - aplikacja koncepcji trajektorii rozwoju powiązań kooperacyjnych rozwiązała ten problem, umożliwiając wyodrębnienie czterech wewnętrznie homogenicznych podzbiorów podmiotów w ramach inicjatywy (kryterium podziału był tutaj charakter wypracowanej przez podmiot relacji współpracy). Różne podzbiory oznaczały różne cele i potrzeby (także zasobowe) podmiotów w nich się znajdujących - w tym także odmienne nastawienie do głównych wyznaczników innowacji otwartych: charakteru poszukiwanej, współdzielonej i wytwarzanej wiedzy oraz zaawansowania relacji współpracy (szeroka vs. wąska) nawiązywanej w ramach inicjatyw.

\section{Innowacje otwarte w perspektywie koncepcji trajektorii rozwoju powiązań kooperacyjnych w inicjatywach klastrowych}

$\mathbf{N}$ a podstawie przeprowadzonych badań empirycznych A.M. Lis ustaliła, iż współpraca w inicjatywach klastrowych może przyjmować różne formy, które rozdzielone na zbiory tworzą hierarchiczny układ składający się z czterech poziomów współpracy: I poziom „Integracja na poziomie jednostkowym”, II poziom „Alokacja i integracja na poziomie procesów”, III poziom „Oddziaływanie na otoczenie” oraz IV poziom „Kreacja i integracja na poziomie organizacyjnym”. Wyodrębnienie tych poziomów nastąpiło poprzez zidentyfikowanie „celów głównych”, wskazujących na kluczowy rodzaj aktywności w inicjatywach klastrowych, zaś podstawą do ich uszeregowania były „wyróżniki poziomu zaawansowania współpracy”, odzwierciedlające podejście przyjmowane przez podmioty klastrowe (podejście indywidualne vs. kolektywne) (tab. 2).

$\mathrm{Na}$ każdym ze zidentyfikowanych poziomów współpracy wyróżniono kluczowe rodzaje zasobów, do których członkowie - ze względu na podejmowane przez nich aktywności - mają ułatwiony dostęp (Lis, 2018). Zasobami, które w świetle stworzonej koncepcji i przeprowadzonych badań dostępne są na każdym wyróżnionym poziomie współpracy, są zasoby relacyjne, stanowiące zbiór relacji $\mathrm{z}$ interesariuszami wewnętrznymi i zewnętrznymi inicjatywy klastrowej (Smolska, 2014). Można zatem stwierdzić, iż $\mathrm{w}$ analizowanych inicjatywach klastrowych otwartość członków na inne podmioty (dotycząca rozmaitych aspektów funkcjonowania przedsiębiorstw, w tym i ich aktywności innowacyjnej) - wyznacznik innowacji otwartych - jest cechą występującą niezależnie od wyróżnionego poziomu współpracy. Otwartość na podejmowanie działań w kooperacji z innymi podmiotami (rozumiana tutaj zarówno jako występowanie $\mathrm{w}$ roli donora, akceptora lub obu rolach jednocześnie) jest zatem immanentną cechą inicjatyw klastrowych, a tym samym czyni z tych superorganizacji naturalne pole do rozwijania innowacji w otwartej formie. Choć zasoby relacyjne są $\mathrm{w}$ inicjatywach klastrowych wszechobecne, to - jak wskazały badania - przejawiają się z różną intensywnością: powiększają się bowiem wraz z przechodzeniem na wyższe poziomy współpracy klastrowej - więzi pomiędzy wybranymi partnerami klastrowymi zacieśniają się, warunkując dostęp do innych rodzajów zasobów, zarówno materialnych, jak i niematerialnych (Lis, 2018).

Tabela 2. Koncepcja trajektorii rozwoju powiązań kooperacyjnych w inicjatywach klastrowych - wybrane elementy koncepcji

\begin{tabular}{|c|c|c|c|c|}
\hline \multirow{2}{*}{ Poziomy współpracy } & \multirow{2}{*}{ Cele główne } & \multicolumn{3}{|c|}{ Wyróżniki } \\
\hline & & Charakter działań & Cele członków & Interesy członków \\
\hline $\begin{array}{l}\text { I poziom: } \\
\text { „Integracja na poziomie } \\
\text { jednostkowym” }\end{array}$ & $\begin{array}{l}\text { Stworzenie bazowej sieci } \\
\text { relacji między klastrowymi } \\
\text { współpartnerami }\end{array}$ & Indywidualny & Indywidualne & Indywidualne \\
\hline $\begin{array}{l}\text { II poziom: } \\
\text { „Alokacja i integracja na } \\
\text { poziomie procesów” }\end{array}$ & $\begin{array}{l}\text { Ułatwienie dostępu do } \\
\text { zwiększonej puli zasobów } \\
\text { Podwyższenie jakości } \\
\text { produktów i usług i/lub } \\
\text { obniżenie kosztów prowadzenia } \\
\text { działalności gospodarczej }\end{array}$ & Kolektywny & Indywidualne & Indywidualne \\
\hline $\begin{array}{l}\text { III poziom: } \\
\text { „Oddziaływanie na } \\
\text { otoczenie” }\end{array}$ & $\begin{array}{l}\text { Umożliwienie oddziaływania } \\
\text { na otoczenie zewnętrzne } \\
\text { organizacji }\end{array}$ & Kolektywny & Kolektywne & Indywidualne \\
\hline $\begin{array}{l}\text { IV poziom: } \\
\text { „Kreacja i integracja na } \\
\text { poziomie organizacyjnym” }\end{array}$ & $\begin{array}{l}\text { Stworzenie warunków do } \\
\text { wykreowania wspólnej wartości } \\
\text { dodanej poprzez połączenie } \\
\text { zasobów przedsiębiorstw } \\
\text { klastrowych }\end{array}$ & Kolektywny & Kolektywne & Kolektywne \\
\hline
\end{tabular}


Samo istnienie powiązań kooperacyjnych nie gwarantuje jednakże wystąpienia efektu synergii, tak charakterystycznego dla inicjatyw klastrowych. Aby ów efekt mógł się pojawić, konieczne jest złączenie zasobów relacyjnych z zasobami innego rodzaju: tylko wtedy uaktywni się potencjał danej relacji. Zasobami o szczególnym znaczeniu zarówno $\mathrm{z}$ punktu widzenia innowacji otwartych, jak i funkcjonowania podmiotów $\mathrm{w}$ inicjatywach klastrowych są zasoby informacyjne. Więzi nawiązane w ramach inicjatyw klastrowych i zbudowana na nich wspólnota klastrowa ułatwiają dostęp do informacji i wiedzy krążących wewnątrz inicjatyw klastrowych - zarówno tych pochodzących od pozostałych partnerów klastrowych, jak i tych wymienianych z otoczeniem inicjatywy, z wykorzystaniem „kluczy” do „strukturalnych dziur” (Burt, 1992). Z perspektywy podejścia zasobowego informacje i wiedza zdobywane $\mathrm{w}$ inicjatywach mogą być postrzegane jako dodatkowy zasób przedsiębiorstwa, a ich umiejętne wykorzystanie może prowadzić do uzyskania lub utrzymania przewagi konkurencyjnej na rynku. O niedającej się przecenić roli wiedzy we współczesnym życiu i prymacie tego zasobu nad innymi najlepiej przekonuje A. Toffler, pisząc: „Sama wiedza okazuje się nie tylko źródłem władzy, ale także najważniejszym składnikiem siły i bogactwa. Mówiąc inaczej, wiedza przestała funkcjonować jako dodatek do władzy pieniądza i władzy pięści, stając się ich istotą. Jest to w rzeczywistości ostateczny wzmacniacz. To jest klucz do czekającego nas przesunięcia władzy, co wyjaśnia, dlaczego walka o kontrolę nad wiedzą i środkami komunikacji roznieca się na całym świecie” (Toffler, 1990).

Zgodnie $\mathrm{z}$ wynikami badań i opracowanymi na ich podstawie założeniami wygenerowanej koncepcji, zasoby informacyjne występują na każdym wyróżnionym poziomie współpracy klastrowej, różnice uwidaczniają się $\mathrm{w}$ rodzaju udostępnianych informacji (Lis, 2018) (tab. 3).

Tabela 3. Poziomy współpracy w inicjatywach klastrowych a dostęp do informacji i wiedzy

\begin{tabular}{|l|l|}
\hline \multicolumn{1}{|c|}{$\begin{array}{c}\text { Poziom } \\
\text { współpracy }\end{array}$} & \multicolumn{1}{c|}{ Rodzaj zasobu } \\
\hline \multirow{2}{*}{ I } & $\begin{array}{l}\text { Dostęp do informacji ogólnych, różnorodnych, } \\
\text { w dużej ilości }\end{array}$ \\
\hline \multirow{2}{*}{ II } & $\begin{array}{l}\text { Dostęp do informacji szczegółowych, } \\
\text { spersonalizowanych }\end{array}$ \\
\cline { 2 - 3 } & $\begin{array}{l}\text { Dostęp do informacji umożliwiających lepszą } \\
\text { identyfikację źródeł zasobów }\end{array}$ \\
\hline \multirow{2}{*}{ III } & $\begin{array}{l}\text { Pierwszeństwo w dostępie do istotnych informacji na } \\
\text { temat otoczenia }\end{array}$ \\
\hline \multirow{2}{*}{ IV } & $\begin{array}{l}\text { Dzielenie się informacjami zarezerwowanymi dla } \\
\text { zaufanych partnerów }\end{array}$ \\
\cline { 2 - 3 } & Uczestniczenie w procesach kreowania nowej wiedzy \\
\hline
\end{tabular}

Źródło: opracowanie własne na podstawie: Lis, 2018

Na I poziomie podmioty klastrowe otrzymują dostęp do informacji na temat samej inicjatywy (i jej członków) oraz najbliższego otoczenia - informacje te $\mathrm{z}$ jednej strony występują zazwyczaj w dużej ilości, są również bardzo zróżnicowane, ale $\mathrm{z}$ drugiej strony - ogólne i słabo spersonalizowane. $\mathrm{Na}$ poziomie II podmioty klastrowe otrzymują dużo bardziej szczegółowe informacje, ściśle dopasowane do ich profilu działalności, co ułatwia im identyfikację źródeł brakujących zasobów. Warto również podkreślić, że na omawianym poziomie zasoby informacyjne uzupełnione są o inne rodzaje zasobów (zasoby materialne, ludzkie i finansowe). Na III poziomie podmioty klastrowe uzyskują pierwszeństwo $\mathrm{w}$ zdobywaniu istotnych informacji na temat zmian zachodzących w otoczeniu, co stawia je na uprzywilejowanej pozycji względem podmiotów spoza inicjatywy klastrowej. Na ostatnim, IV poziomie oprócz zasobów informacyjnych pojawiają się zasoby wiedzy. Dostęp do wiedzy w inicjatywach klastrowych jest jednak ograniczony - przywilej ten mają jedynie wybrani członkowie angażujący się w najbardziej dojrzałe formy współpracy klastrowej (jak np. udział w konsorcjach projektowych, grupach zadaniowych). W ramach podejmowanej aktywności wspólnie uczestniczą w procesach tworzenia, gromadzenia i dzielenia się wiedzą, a także informacjami zarezerwowanymi jedynie dla zaufanych partnerów (Lis, 2018).

Opisane powyżej mechanizmy kooperacji - odmienne dla różnych poziomów współpracy - pozwalają również wyciągnąć wnioski na temat głównych kierunków innowacji otwartych, obieranych przez podmioty tworzące badane inicjatywy klastrowe. Ciekawe (i warte dalszego analizowania w kolejnych badaniach) wydaje się to, że spośród trzech wyróżnionych przez $\mathrm{H}$. Chesbrougha i omówionych wcześniej typów (a tym samym kierunków) innowacji otwartych - „Outside-In”, „Inside-Out” oraz „Coupled” - w analizowanych inicjatywach klastrowych wystapiły tylko dwa $\mathrm{z}$ nich: innowacje otwarte typu "Outside-In” i podejście „Coupled”. Żaden z czterech wyróżnionych poziomów współpracy nie cechował się (jako względnie homogeniczny podzbiór) tendencjami pozwalającymi zaklasyfikować tworzące go podmioty do kategorii otwartych innowacji w wersji "Inside-Out”. Nie znaczy to, że wśród badanych podmiotów nie wystąpiły pojedyncze przedsiębiorstwa działające zgodnie $\mathrm{z}$ tą ideą - było ich jednak zdecydowanie zbyt mało, aby wywrzeć znaczący wpływ na całą kategorię teoretyczną (czyli wyznaczyć specyfikę któregoś z poziomów współpracy).

Wspomniane wyżej skupienie podmiotów $\mathrm{z}$ inicjatyw klastrowych na jedynie dwóch z trzech możliwych kierunków („Outside-In” i „Coupled”) zyskuje głębszy wymiar w momencie wykorzystania $\mathrm{w}$ analizie dwóch dodatkowych zmiennych: cenności (wartości) zasobów dostępnych $\mathrm{w}$ inicjatywie i idącej za tym trudności $\mathrm{w}$ ich imitowaniu oraz siły (bliskości) relacji podmiotu z partnerem klastrowym. Można bowiem stwierdzić, że wraz $\mathrm{z}$ przechodzeniem na wyższe etapy rozwoju powiązań kooperacyjnych zasoby (otrzymywane, oferowane, wymieniane lub wspólnie wytwarzane) stają się coraz cenniejsze i trudniejsze do imitacji, zaś dostęp do nich zdeterminowany jest w coraz większym stopniu siłą więzi partnerskich (rys. 1). 


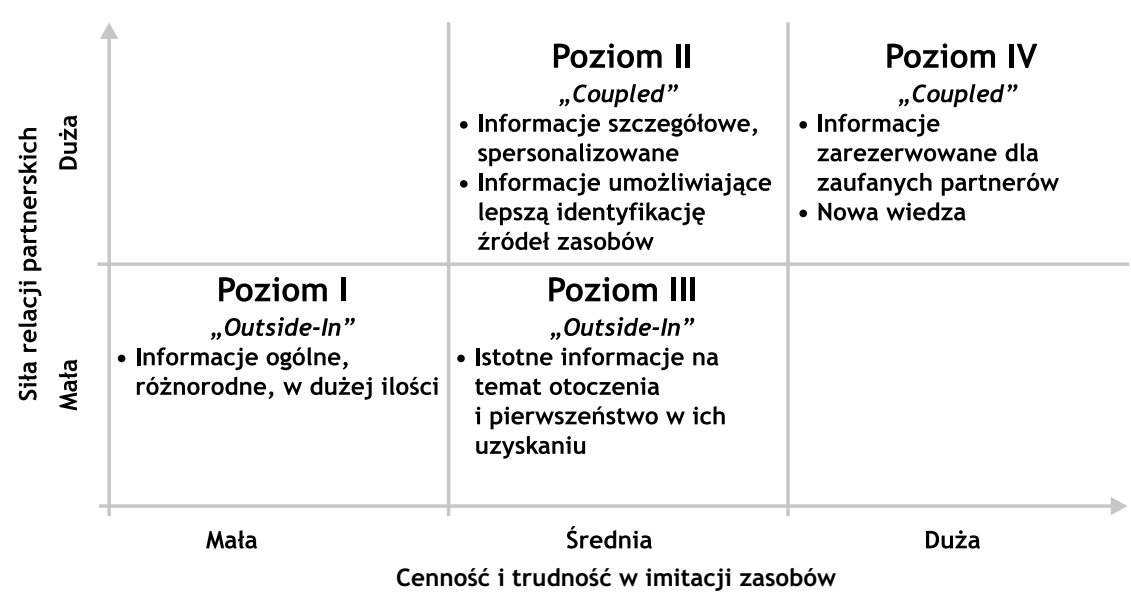

Rys. 1. Dostęp do informacji i wiedzy w inicjatywach klastrowych: powiązanie koncepcji trajektorii rozwoju z koncepcją innowacji otwartych

Źródło: opracowanie własne na podstawie: Lis, 2018

Przedstawiona wyżej macierz dzieli cechy na podpoziomy odpowiadające intensywności przejawiania się ich na danym poziomie współpracy: „mała”, „średnia” i „duża” w przypadku „Cenności i trudność w imitacji zasobów” (oś X) oraz „mała” i „duża” w odniesieniu do „Siły relacji partnerskich (oś Y)”. Zasoby informacyjne przypisane do I i III poziomu nie wymagały ustanowienia silnych relacji pomiędzy partnerami ( $w$ ich rozpowszechnianiu wystarczające są technologie teleinformatyczne), a ich wartość i unikatowość należy ocenić jako niską (I poziom), ewentualnie średnią (III poziom). Przeciętne okazały się również cenność i trudność $\mathrm{w}$ imitacji zasobów informacyjnych na II poziomie, $\mathrm{z}$ tym że w większym stopniu bazowała ona na kontaktach pomiędzy podmiotami klastrowymi - zależnymi od dotychczasowej wzajemności i otwartości partnerów w dzieleniu się informacjami. Najbardziej cenne i unikatowe były informacje poufne i wiedza przekazywane pomiędzy członkami na najwyższym, IV poziomie współpracy. Barierą w dostępie do nich było najczęściej zaufanie (a ściśle jego brak), które nie zostało wytworzone pomiędzy partnerami na wcześniejszych poziomach współpracy klastrowej.

\section{Dyskusja}

U zupełniając przeprowadzone wyżej rozważania o wątki związane $z$ kierunkami innowacji otwartych, obieranymi przez przedsiębiorstwa klastrowe w ramach poszczególnych etapów rozwoju powiązań kooperacyjnych, należy zwrócić uwagę na dość specyficzne umiejscowienie poziomów współpracy i przyporządkowanych im kierunków innowacji otwartych do pozycji (komórki) w macierzy. Dość wyraźnie zaznaczają się tutaj przedstawione w dalszej części artykułu kwestie:

- Żaden z wyróżnionych poziomów współpracy w inicjatywach klastrowych nie wpisał się w obszar powstały na skrzyżowaniu zasobów małej wartości i dużej siły relacji partnerskich.

Do korzystania lub przynajmniej współkorzystania z zasobów o niewielkim znaczeniu i małej trudności w imitowaniu nie potrzeba tego, aby podmioty wytwa- rzały silną więź między sobą. To raczej współkorzystanie z zasobów (szczególnie oparte o relacje uczciwej wymiany i wzajemności) może przełożyć się po pewnym czasie na nawiązanie silnych relacji partnerskich między podmiotami - wtedy jednak - jak wskazały badania A.M. Lis - będą one już zainteresowane innymi formami współpracy i innymi rodzajami zasobów (głównie z poziomów II i IV).

- Żaden z wyróżnionych poziomów współpracy w inicjatywach klastrowych nie wpasował się w obszar utworzony na przecięciu zasobów o dużym znaczeniu i niewielkiej sile relacji partnerskich.

Powyższe jest zgodne z poczynionymi już wcześniej obserwacjami, zgodnie z którymi dostęp do coraz cenniejszych zasobów (dostępnych na wyższych etapach rozwoju powiązań kooperacyjnych) wymaga istnienia silniejszej więzi między współpracującymi podmiotami (w szczególności: większego zaufania).

- Poziomy współpracy I i III, korespondujące swoją specyfiką z innowacjami otwartymi w formie "Outside-In” są jednocześnie poziomami opartymi na niewielkiej sile relacji partnerskich.

Sednem poziomów I i III jest koncentracja na absorpcji informacji i wiedzy z zewnątrz, przy czym istnieje znacząca różnica między tym, co jest „na zewnątrz” podmiotów na I poziomie współpracy, a czym jest „zewnętrze” dla przedsiębiorstw na poziomie III. „Zewnętrze” na I poziomie to w pierwszej kolejności inicjatywa klastrowa (dopiero w drugiej kolejności - jej otoczenie), a zatem podmioty klastrowe czerpiące wiedzę i informację na I poziomie korzystają przede wszystkim z potencjału oferowanego przez koordynatora i pozostałych członków inicjatywy. Inaczej wygląda to na poziomie III - w tym przypadku pożądane przez podmiot zasoby pochodzą przede wszystkim spoza inicjatywy. Podmioty kooperujące na III poziomie są zatem skupione na absorpcji wiedzy i informacji niedostępnych w samej inicjatywie (co stanowi istotny element tworzenia ich przewagi konkurencyjnej).

- Poziomy współpracy II i IV, przypisane do innowacji otwartych typu "Coupled”, zgodnie ulokowały się w górnej części macierzy, a więc w obszarze wyznaczonym przez dużą siłę relacji partnerskich. 
Na II poziomie kooperujące podmioty wymieniały się informacjami i wiedzą ściśle dopasowanymi do swoich potrzeb. Zasoby te były jednak bardziej istotne niż informacje transferowane na poziomie I - można im przypisać średnie (przeciętne) znaczenie. Najważniejsze - z punktu widzenia budowania przewagi konkurencyjnej - przepływy informacji oraz wytwarzanie nowej wiedzy zachodziły na IV poziomie współpracy klastrowej. Współpraca o takim stopniu zaawansowania występowała jednak bardzo rzadko (przynajmniej w badanych inicjatywach klastrowych). Barierą w jej osiągnięciu był z pewnością wysoki stopień wzajemnego zaufania, jakim muszą obdarzać się nawzajem podmioty kooperujące.

Ze względu na brak w literaturze przedmiotu publikacji łączących tematykę rozwoju współpracy w inicjatywach klastrowych i innowacji otwartych niemożliwe jest skonfrontowanie przeprowadzonych rozważań z innymi, podobnymi podejściami. Należy również podkreślić, iż przedstawione wyżej obserwacje i refleksje dotyczą konkretnych, poddanych badaniu inicjatyw klastrowych - nie można wykluczyć jednak, że zwiększenie próby badawczej i włączenie do badania inicjatyw klastrowych $\mathrm{z}$ innych sektorów gospodarki nieco zmieniłoby charakter poczynionych ustaleń.

\section{Podsumowanie}

D ziałanie w warunkach ograniczonej ilości zasobów jest dla przedsiębiorstw codziennością. Codziennością jest więc także i podejmowanie prób minimalizowania szkód wynikających $\mathrm{z}$ braku zasobów jednego rodzaju oraz maksymalizowanie korzyści płynących z posiadania nadwyżek zasobów w innych obszarach. Najlepszą - jak do tej pory - metodą radzenia sobie $\mathrm{z}$ funkcjonowaniem $\mathrm{w}$ warunkach dysponowania niezbalansowanymi (i niewystarczającymi) zasobami jest kooperacja $\mathrm{z}$ innymi podmiotami i wymiana lub wspólne wytwarzanie zasobów o szczególnym znaczeniu dla wszystkich zaangażowanych stron (szczególnie taka kooperacja, która kończy się opracowaniem rozwiązań innowacyjnych). Wiadomo jednak, że nie każdy akt współpracy będzie tak samo efektywny - liczba czynników wpływających na efekt końcowy każdej kooperacji jest zbyt duża, aby wszystkie udało się mieć pod kontrolą.

Współpraca w inicjatywach klastrowych pozwala zaangażowanym przedsiębiorstwom na osiągnięcie efektu synergii, a więc wspólne odniesienie korzyści większych niż w przypadku, gdyby każdy z podmiotów podejmował podobne działania samodzielnie. Dotyczy to zarówno sytuacji zwykłej wymiany zasobów materialnych, jak i transferu dóbr niematerialnych oraz - na poziomie najbardziej zaawansowanym - wspólnego wytwarzania nowej wiedzy (kluczowego z punktu widzenia kreowania rozwiązań innowacyjnych - szczególnie tych prowadzonych zgodnie z ideą innowacji otwartych). Patrząc przez pryzmat przedstawionych wcześniej wyników badań oraz wniosków wyciągniętych na ich podstawie, można zauważyć dużą zgodność między specyfiką powiązań kooperacyjnych nawiązywanych $\mathrm{w}$ ramach badanych inicjatyw klastrowych a wskazanymi przez H. Chesbrougha (2003) zasadami innowacji otwartych.

Za nieco zaskakujący uznać jednak należy fakt, że żaden $\mathrm{z}$ zaobserwowanych w badaniu poziomów współpracy nie pokrył się z odśrodkową ścieżką "Inside-Out”, wyróżnioną przez $\mathrm{H}$. Chesbrougha jako jedna $\mathrm{z}$ trzech możliwych do obrania podczas zmierzania $\mathrm{w}$ stronę innowacji otwartych. Można za to stwierdzić, iż preferowanymi przez podmioty klastrowe formami kooperacji były ścieżki: dośrodkowa („Outside-In”) i sprzężona („Coupled”). Przedsiębiorstwa składające się na badane inicjatywy klastrowe zorientowane były na czerpanie zasobów (przede wszystkim w znaczeniu informacji i wiedzy) z zewnątrz: albo na krótki dystans - od innych podmiotów z inicjatywy (koordynatora i poszczególnych członków) (I poziom współpracy), albo na większy dystans - spoza inicjatywy (III poziom) lub też wybierały wariant mieszany (sprzężony), w którym dochodziło do wymiany zasobów (przede wszystkim informacji i wiedzy) między zaangażowanymi podmiotami (II poziom) albo ich wspólnego kreowania (IV poziom).

Wykorzystanie idei innowacji otwartych w kreowaniu współpracy przedsiębiorstw i innych podmiotów tworzących inicjatywy klastrowe jest obiecujące zarówno pod względem dalszych inspiracji teoretycznych (a więc prowadzenia naukowej refleksji), jak i osiąganych rezultatów praktycznych (rzeczywistej kooperacji podmiotów klastrowych). Warto przy tym jednakże pamiętać, że współpraca taka nie może być planowana $\mathrm{z}$ góry dla całej inicjatywy klastrowej, ale $\mathrm{z}$ uwzględnieniem istniejących $\mathrm{w}$ tych strukturach wewnętrznych podziałów (np. $\mathrm{w}$ formie zaprezentowanych w tej publikacji poziomów rozwoju powiązań kooperacyjnych). Podmioty tworzące struktury klastrowe różnią się bowiem między sobą pod zbyt wieloma względami, aby traktowanie ich jako homogenicznej masy przyniosło oczekiwane, pozytywne rezultaty. Wskazówką dla wszystkich chcących w praktyce wcielać ideę innowacji otwartych i pragnących pobudzić współpracę w ramach inicjatyw klastrowych winno również być skupienie uwagi na tworzeniu warunków sprzyjających kształtowaniu się wzajemnego zaufania wśród członków. Tylko to bowiem umożliwia wejście na dwa najbardziej prorozwojowe poziomy współpracy (II i IV) oraz w największym stopniu przełoży się na kreowanie rozwiązań innowacyjnych w duchu innowacji otwartych.

\section{dr Anna Maria Lis Politechnika Gdańska Wydział Zarządzania i Ekonomii ORCID: 0000-0002-1527-7796 e-mail: Anna.Lis@zie.pg.gda.pl}

\author{
dr Adrian Lis \\ Collegium Civitas \\ ORCID: 0000-0003-4801-704X \\ e-mail: adrian.lis@civitas.edu.pl
}




\section{Przypisy}

1) W swoim artykule „Potencjał relacyjny a innowacyjność przedsiębiorstwa - w kierunku open innovation" A. Zakrzewska-Bielawska (2016) wskazuje pozycje literaturowe zarówno wspierające tę hipotezę, jak i jej przeciwstawne.

2) Jak wskazali H. Chesbrough i M. Bogers - w roku 2003, kiedy H. Chesbrough wydał przełomową książkę „Open Innovation. The New Imperative for Creating and Profiting from Technolo$g y$ ”, wyszukiwarka Google zwracała około 200 linków w odpowiedzi na zapytanie „Open Innovation”. W kwietniu 2012 roku liczba odpowiedzi na to samo zapytanie obejmowała 483 miliony linków (Chesbrough, Bogers, 2014).

3) West i Bogers zidentyfikowali 165 artykułów, w których przedmiotem analizy były innowacje otwarte: $118 \mathrm{z}$ nich przynajmniej w części podejmowało wątek innowacji „Outside-In”, 50 - „Inside-Out”, zaś w 70 publikacjach skupiono uwagę także i na wariancie „Coupled” (West, Bogers, 2014).

4) Badane inicjatywy zrzeszają podmioty reprezentujące różne sektory gospodarki - w przypadku inicjatyw ICT jest to m.in. Dział 26 i 27 (sekcja C) oraz 61, 62 i 63 (sekcja J), w przypadku inicjatyw metalowych - Dział 24, 25, 28 i 33 (sekcja C).

\section{Bibliografia}

[1] Balconi M., Breschi S., Lissoni F. (2004), Networks of Inventors and the Location of Academic Research: An Exploration of Italian Patent Data, „Research Policy”, Vol. 33, No. 1, pp. 127-145.

[2] Bogers M. (2011), The Open Innovation Paradox: Knowledge Sharing and Protection in R\&D Collaborations, „European Journal of Innovation Management", Vol. 14, No. 1, pp. 93-117.

[3] Burt R.S. (1992), Structural Holes, Harvard University Press, Cambridge.

[4] Chesbrough H. (2003), The Era of Open Innovation, „MIT Sloan Management Review", Vol. 44, No. 3, pp. 35-41.

[5] Chesbrough H.W. (2006), Open Innovation: A New Paradigm for Understanding Industrial Innovation, [in:] W. Chesbrough, W. Vanhaverbeke, J. West (eds.), Open Innovation: Researching a New Paradigm, Oxford University Press, Oxford, pp. 1-19.

[6] Chesbrough H., Bogers M. (2014), Explicating Open Innovation: Clarifying an Emerging Paradigm for Understanding Innovation, [in:] H. Chesbrough, W. Vanhaverbeke, J. West (eds.), New Frontiers in Open Innovation, Oxford University Press, Oxford, pp. 3-28.

[7] Cumming B.S. (1998), Innovation Overview and Future Challenges, „European Journal of Innovation Management”, Vol. 1, No. 1, pp. 21-29.

[8] Hamel G., Prahalad C.K. (1993), Strategy as Stretch and Leverage, „Harvard Business Review”, Vol. 71, No. 2, pp. 75-84.

[9] Kozarkiewicz A. (2010), Współczesne trendy w innowacyjności: $w$ kierunku otwartych innowacji, „Przegląd Organizacji”, Nr 5, s. 20-23.

[10] Lis A.M. (2018), Wspótpraca w inicjatywach klastrowych. Rola bliskości w rozwoju powiązań kooperacyjnych, Wydawnictwo Politechniki Gdańskiej, Gdańsk.

[11] Lis A.M., Lis A. (2014), Zarządzanie kapitałami w klastrach. Kapital społeczny, kulturowy, ekonomiczny i symboliczny w strukturach klastrowych, Difin SA, Warszawa.
[12] Lockett A., Thompson S., Morgenstern U. (2009), The Development of the Resource-based View of the Firm: A Critical Appraisal, „International Journal of Management Reviews", Vol. 11, No. 1, pp. 9-28.

[13] Lundvall B.A. (1992), National Systems of Innovation: Towards a Theory of Innovation and Interactive Learning, Frances Pinter, London.

[14] Marques J.P. (2014), Closed versus Open Innovation: Evolution or Combination? „International Journal of Business and Management", Vol. 9, No. 3, pp. 196-203.

[15] Pfeffer J., Salancik G. (2003), The External Control of Organizations. A Resource Dependence Perspective, Stanford Business Books, Stanford.

[16] Porter M.E. (1998), Clusters and the New Economics of Competition, „Harvard Business Review”, Vol. 76, No. 6, pp. 77-90.

[17] Porter M.E. (2000), Location, Competition, and Economic Development: Local Clusters in a Global Economy, „Economic Development Quarterly”, Vol. 14, No. 1, pp. 15-34.

[18] Porter M.E. (2001), Porter o konkurencji, PWE, Warszawa.

[19] Romanowska M. (2015), Innowacyjne przedsiębiorstwo $w$ nieinnowacyjnej gospodarce, „Przegląd Organizacji”, Nr 8, s. $4-8$.

[20] Schumpeter J.A. (1911), The Theory of Economic Development, Harvard University Press, Cambridge.

[21] Schumpeter J.A. (1934), The Theory of Economic Development: An Inquiry into Profits, Capital, Credit, Interest and the Business Cycle, „Harvard Economic Studies”, Vol. 46, Harvard College, Cambridge.

[22] Schumpeter J.A. (1939), Business Cycles. A Theoretical, Historical and Statistical Analysis of the Capitalist Process, McGraw-Hill Book Company, New York, Toronto, London.

[23] Schumpeter J.A. (1942), Capitalism, Socialism, and Democracy, Harper \&Brothers, New York, London.

[24] Smolska M. (2014), Klaster jako generator kapitału relacyjnego i jego rola $w$ rozwoju regionu zachodniopomorskiego, Zeszyty Naukowe Uniwersytetu Szczecińskiego. Studia i Prace Wydziału Nauk Ekonomicznych i Zarządzania, Nr 37(2), s. 323-333.

[25] Sölvell Ö., Lindqvist G., Ketels C. (2003), The Cluster Initiative Greenbook, Ivory Tower, Stockholm.

[26] Sölvell Ö., Lindqvist G., Ketels C. (2006), Zielona Ksiegga Inicjatyw Klastrowych. Inicjatywy klastrowe $w$ gospodarkach rozwijajacych się $i w$ fazie transformacji, PARP, Warszawa.

[27] Toffler A. (1990), Powershift. Knowledge, Wealth, and Violence at the Edge of the 21st Century, Bantam Books, New York, Toronto, London, Sydney, Auckland.

[28] West J., Bogers M. (2014), Leveraging External Sources of Innovation: A Review of Research on Open Innovation, „Journal of Product Innovation Management", Vol. 31, No. 4, pp. 814-831.

[29] Zagóra-Jonszta U. (2015), Teoria rozwoju gospodarczego $i$ „twórczej destrukcji” Schumpetera oraz jej aktualność, „Optimum. Studia Ekonomiczne”, Nr 3(75), s. 20-31.

[30] Zakrzewska-Bielawska A. (2016), Potencjat relacyjny a innowacyjność przedsiębiorstwa - w kierunku open innovation, „Management Forum”, Nr 4(1), s. 3-10. 


\section{Open Innovation in Cluster Initiatives}

\section{Summary}

The specificity of cluster initiatives makes them an ideal basis for implementing the idea of open innovation - they make it easier to establish contacts with other entities, rely on the openness of their members and building relationships based on trust, provide a platform for resource exchange (primarily information and knowledge), and joint creation of innovative solutions. The article presents theoretical considerations regarding the use of the concept of open innovation in cluster initiatives. The aim of the article is to present the links between levels of cluster cooperation and elements constituting open innovation. The main research method was the review of the literature and the theoretical application of the original concept of the cooperative relationships development trajectory, developed on the basis of research on cooperation in cluster initiatives and the role of proximity in the development of this cooperation. The considerations carried out by the authors confirmed the importance of trust as a criterion for access to the most valuable information and knowledge in cluster initiatives. However, they also indicated that none of the four identified levels of cluster cooperation corresponded with open innovation in the form of "Inside-Out". The levels of cooperation I and III were within "Outside-In", while levels II and IV corresponded to the form "Coupled". Keywords:

\section{Keywords}

cluster, cluster initiative, open innovation, cooperation 